\title{
HUMANIZING TAIBAH UNIVERSITY CAMPUS OPEN SPACES IN MADINAH: TOWARD A SUSTAINABLE ENVIRONMENT FOR WALKABILITY AND GREEN SPACES
}

\author{
USAMA ABD EL-HAMEED NASSAR* \\ ${ }^{1}$ Department of Architecture and Urban Planning, Faculty of Engineering, Suez Canal University, Ismailia, Egypt. \\ ${ }^{2}$ Architectural Engineering Department, College of Engineering, Taibah University, Almadinah Almunawarah, KSA.
}

*Corresponding author: usama.a.nassar@gmail.com

Submitted final draft: 12 June $2020 \quad$ Accepted: 25 June 2020

http://doi.org/10.46754/jssm.2021.04.017

\begin{abstract}
Open spaces on university campuses create an active academic environment and a vibrant, active social life. This paper aims to answer the question, "Under which conditions does a university campus change from subduing students' social life to enhancing it?" By studying the Taibah University (TU) campus in Madinah, Saudi Arabia, this research provides an initial step to enhance walkability and pedestrian movement for users. The study consists of main parts: theoretical background and literature review to reach design guidelines, site analysis and survey followed by discussion of results, and a final urban proposal for humanizing the campus along with the recommendation to use the campus as a catalyst to humanise Madinah. Analysing TU will be completed through a site visit and picture documentation. The research has also engaged the students' opinions through survey assessment of the campus. The survey study was done in fall 2019 through students' participation in the graduation project in the Architecture Engineering Department at Taibah University to study the urban context of the campus and propose new uses for buildings. The finding of this paper will propose important steps to increase campus walkability; social sustainability and stress on the main future studies to strengthen the research results.
\end{abstract}

Keywords: Campus outdoor space, humanizing, taibah university, social sustainability, walkability.

\section{Introduction}

Our cities are seeing rapid population and urban growth nowadays. Accordingly, most of the university campuses became trapped by the fabric of the cities in which they are situated. City planners used to choose sites for new university campuses in large areas outside a city's urban border. As for the existing universities, there is an urgent need to reconsider the significant role that they play in society. A university campus has a great impact on the social and cultural development of the students, community and the surrounding environment. Consequently, there are numerous new studies that discuss and stress the important role of university campuses not only in education but as a centre of community development (Alhusban et al., 2019; Gulwadi et al., 2019; Hajrasouliha, 2016; Way, 2016; Khadem at al., 2019).
The word "campus" was first used in the context of an American university in the 18th century, although the country's first university facilities were found in the 17th century at the University of Princeton (Turner, 1984). Literature review shows that universities consist of different features and identities, which can be structured in three different aspects: mission, character, and focus (Campos Calvo-Sotelo, 2011; Conceição \& Heitor 1999, 2001; Kenney $\&$ Kenney, 2005). With these aspects, university campuses have shaped and translated their physical setting and produced social interaction. Taibah University (TU) campus lies in Madinah a fast-growing urban city and the second holy city in the Kingdom of Saudi Arabia (KSA). Nowadays, there is a growing need to redesign the campus as a role model to humanize the city and engage students with the local community. 
In this framework, the aim of this paper is to understand how the TU campus (open spaces, activities, building uses, relationship between green open spaces and parking areas, etc.) can be transformed into a walkable, eco-friendly areas that initiate pedestrian movement.

The paper is structured in main parts, as shown in Figure 1, starting with the literature review of university campus open spaces and discussing their planning principles, then studying successful international examples to determine the positive and negative impacts as a step to conclude design guidelines to analyze the TU campus's open space network as an initial step to redesign to campus.

The paper will discuss the major findings of site analysis and ends by proposing an urban design to achieve walkability and create a humanized environment for students that stimulates different types of activities and creates sustainable social community on campus.

\section{University Campus Open Spaces}

"University campus" is a term that refers to a space designed by either the government or a private organization for use in the education and residence of college students; it includes buildings and other physical elements found in the associated area (Isiaka \& Siong, 2008;
Bacharel, 2015). Peter Gisolfi stated that "campus" can be defined as the arrangement of buildings and open spaces that shapes the physical character of an institution (Peter Gisolfi \& Associates, 2008).

According to Salama (2008), campuses' outdoor open spaces should encourage a social and intellectual environment and provide the atmosphere for gatherings and informal activities. He mentioned Qatar University's campus as an example for creating a series of open spaces and partially covered courtyards, along with small gardens and fountains to create a better visual experience (Salama, 2008). This part of the research will focus on the importance of campus open spaces and the different challenges involved in creating a successful environment to enrich the educational process.

\section{Importance of Campus Open Spaces}

Each university's campus should reflect its social and cultural objectives, as every type of behavior and activity requires a space with a different size, shape, and furniture (Shepley Bulfinch Richardson \& Abbot, 2007). People's experience on each campus is strongly affected by its visual quality. The more unique its visual identity and quality, the more it may attract students and faculty members (Dober, 2000).

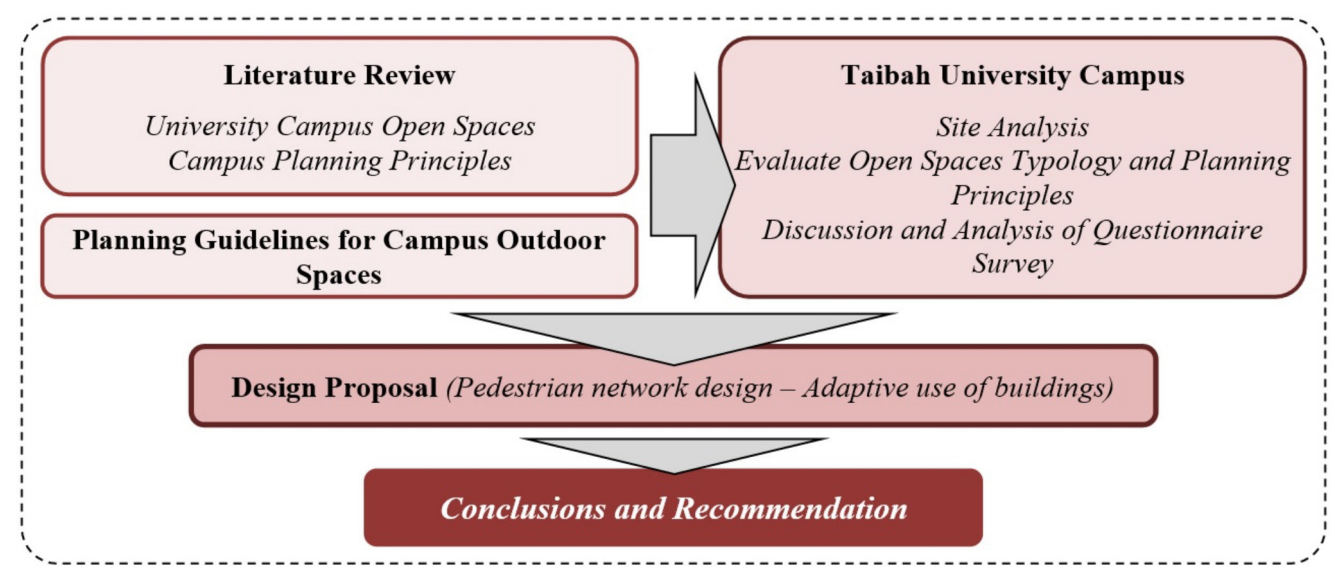

Figure 1: Structure of the research 


\section{Challenges in University Campus Open Spaces}

University campuses' open spaces have many design challenges and problems, which can be listed as follows:

- Perception of campus open spaces in the $60 \mathrm{~s}$

The design of campus open spaces was ignored in the past, always treated as the extra spaces between buildings. Usually, designers focused on buildings, giving less care to the surrounding spaces (Turner, 1984). Outdoor open spaces on campuses were decorated only for appearance, not for users; whatever the campus's location, its plan was always a distribution of buildings surrounded by the spaces left between them (Marcus, 1998).

\section{Traditional Design Process}

Usually, the community around any campus is not a part of the design process of open spaces. The design of any campus always follows the same steps: professionals design the college buildings, get approval from the administration, then start construction. Sometimes, alternative designs are presented to the community, but just to review ideas, not to get their input or learn about their needs. In other words, designers and professionals tend to make their own design decisions without considering users' preferences and needs (Abu-Ghazzeh, 1999).

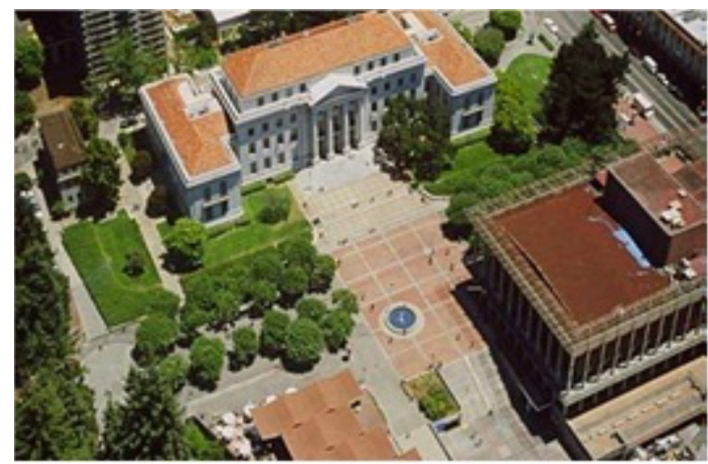

Figure 2: Sproul Plaza in University of California, Berkeley (University of California Berkeley, 2019)

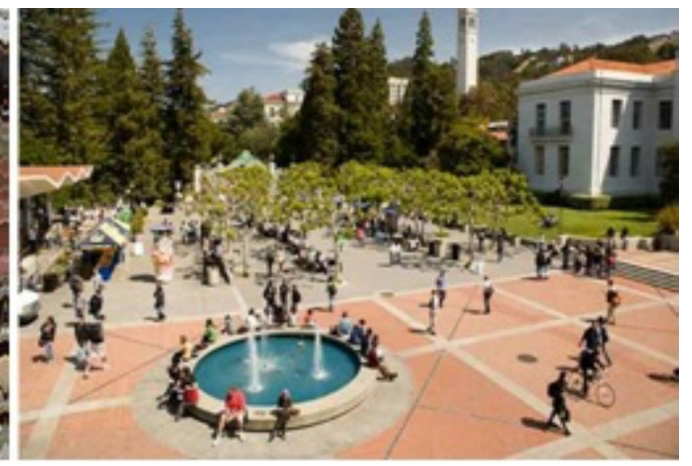

Figure 2 shows a successful example of a campus open space. The University of California at Berkeley's Sproul Plaza is very central and connected to pedestrian entry. The plaza's linear design accommodates large pedestrian flow, with seating areas off to the side to accommodate different types of activities (Marcus \& Francis, 1997).

\section{The Way People Act in Campus Open Spaces}

The landscape in campus open spaces used to be designed to form the visual image of the university and not for students to use. Each material is selected for the campus's beauty. Even the texture and color of landscape elements were a green carpet on which buildings were placed (Dober, 2000).

\section{How to Make Successful Campus Open Spaces}

According to Yildiz and Sener, the quality of outdoor spaces on campuses is associated with the concept of "use value." It is calculated according to the components of frequency and density of activity, along with the time and density of uses (Yild1z \& Sener, 2003). It is important to determine the use value and its role in campus design to improve the quality of spaces. These open spaces act in different ways relative to different criteria, as shown in Figure 3 (Y1ld1z \& Sener, 2006; Özkan et al., 2017; Lenz-Rashid, 2018). 


\section{Building Frame}

Open spaces on campuses are shaped by building edges. The distance between buildings and their heights determine the sense of openness and enclosure of every space and certainly affect the users' experience.

\section{Landscape and Paths}

The distribution of landscape elements, plazas, paths, and green lawns determines the way students will interact with each space. Also, special technology landscape features can be used to satisfy students' needs.

\section{Spatial Organization}

The arrangement of trees, shading elements, and other vertical landscaping affects the different visual landscape image, creating complexity and providing a rich experience of outdoor spaces.

\section{Trees}

Some famous universities can be defined by trees. For example, the campus of the University of Texas at Austin is known for its amazing old oak trees. These trees were planted long ago to form the image of spaces.

\section{Microclimate}

Campus open spaces can accommodate a comfortable microclimate by using such strategies as building orientation to limit heat gain and avoiding the use of certain surfaces that absorb heat (Halsband, 2005).

Figure 3: Criteria of successful campus open spaces

\section{Open Space Typology on Campuses}

Every university should have a mission to achieve on both academic and social level. One of the most powerful languages to express this is the large range of open space typologies on the campus. Figure 4 shows the different types of open space typologies on most university campuses, either according to the different activities that occur in each space or due to its location and accessibility on the campus (Alhusban et al., 2019; Hajrasouliha, 2016; Way, 2016; Khadem et al., 2019.

\section{Campuses Spaces and Planning Principles}

An analysis and literature review shows an insufficiency of existing studies about campus open spaces. For several decades, the matter of form versus function was ignored in the architectural and design process of university campuses. Since the goal of this paper is to create a better environment for walkability and green spaces as a step to humanise the TU campus, this section will provide a better understanding of how university campuses work. The following main points will be discussed:

- Campus outdoor spaces as learning spaces: What are the different types of learning spaces on the campus, both formal and informal?

- Campus planning design in the last 20 years: Overview of the different recent typologies of open spaces at famous successful universities.

- The main planning principles of campus design: When designing a campus master plan, how can one create a distinctive sense of space?

\section{Campus Outdoor as a Learning Space}

The literature review shows that a student campus needs spaces designed as informal learning spaces that foster physical movement, social engagement, interaction, and collaboration as primary elements of the students' learning experiences (Bacharel, 2015; Jamieson, 2003). Table 1 shows the differences between formal and informal learning in outdoor campus spaces. 


\section{Types of activities}

\section{Active recreation}

The purpose is providing the students with recreation fields for both formal and unorganized sports activities. These fields have the size of a soccer field and require storage facilities and seating areas (temporary or permanent)

\section{Passive recreation}

These are differently sized spaces that promote quiet study. Their walkways are paved using stone or brick They are located away from noise and active spaces near academic areas and may be designed to protrude the view of a building or other landscape features.

\section{Open space size}

\section{Small gathering areas}

These spaces serve audiences of a specific building and are used for cultural presentations, informal classes, and promenades. Usually, they are quiet zones (with low-traffic pedestrian walkways) framed by buildings (administration, culture, and academic).

\section{Large gathering areas}

They are large spaces located in the most active areas on campus for students gathering such as concerts, outdoor classes, and graduations ceremonies. These spaces are framed by natural features, roads, and buildings such as large lawns and quads.

\section{Buildings' forms}

\section{Spaces shaped by buildings}

It is important to develop interstitial outdoor spaces that are framed by the built environment of university campuses to complement the building interiors. These spaces are located throughout a campus and have different sizes and landscapes.

\section{Buildings' forecourts}

The forecourt is located at the building's main entrance, and it is the relationship between indoors and outdoors. It includes seats, paving, landscape at the edge, art, and fountains. It must be wide enough to accommodate students during class change.

\section{Spiritual and psychological aspects}

\section{Symbolic spaces}

Memorable campuses are defined by a significant symbol. This icon could be exterior spaces, landscape, or architecture. These outdoor spaces give identity to campus. Its quality is derived by time, and its landscape needs regular and high-level care.
Discovered spaces

Sometimes, memories are made in spaces "off the beaten path." These spaces are different throughout the campus, but they are rich of landscape, using highquality of materials and site furniture (e.g., comfortable benches close to a flower box).

Figure 4: Typology of different types of open spaces on a university campus

Although there is not a broad literature on how open spaces should be designed to foster learning on campus, there are some concepts that enhance learning in open campus spaces.

\section{Learning between Students}

In a traditional campus learning environments, spontaneous conversation among students usually interrupts the silence of a classroom at the end of the lecture or during breaks (Brown \& Long, 2006). Although it is not the type oflearning that teachers intend, these conversations can turn into beneficial interactions in which students share knowledge or gain new information (Kolb $\&$ Kolb, 2005). The existence of shared public spaces like cafeterias, dining halls, or a student union on campus increases the chances and rates of interactions among students.

\section{Collaboration}

Parallel to the developments and alterations in pedagogy, group works have been encouraged by educators, and more collaborative teamwork is taking place outside the formal learning environments. Students who are attuned to this new trend have started to seek alternative 
Table 1: Types of university learning spaces

\begin{tabular}{|c|c|c|}
\hline & Formal Learning & Informal Learning \\
\hline Definitions & $\begin{array}{l}\text { Learning that is totally institutional } \\
\text { and planned. }\end{array}$ & $\begin{array}{l}\text { Learning that is mainly experiential } \\
\text { and non-institutional. }\end{array}$ \\
\hline $\begin{array}{l}\text { Learning } \\
\text { Spaces }\end{array}$ & $\begin{array}{l}\text { - classrooms } \\
\text { - laboratories } \\
\text { - auditoriums } \\
\text { - performance rooms } \\
\text { - computer laboratories } \\
\text { - design studios } \\
\text { - libraries }\end{array}$ & $\begin{array}{l}\text { - outdoor study areas } \\
\text { - cafeterias } \\
\text { - dormitories } \\
\text { - areas between faculty buildings } \\
\text { - student union } \\
\text { - student clubs } \\
\text { - campus open spaces }\end{array}$ \\
\hline Examples & $\begin{array}{l}\text { - lecture-based learning } \\
\text { - workshops } \\
\text { - conferences and seminars }\end{array}$ & $\begin{array}{l}\text { - conversational learning } \\
\text { - self-directed learning } \\
\text { - performance planning } \\
\text { - learning from others }\end{array}$ \\
\hline
\end{tabular}

informal study areas. These alternative spaces were used as social learning spaces in which students get the chance to learn about new issues in a more informal environment (Jamieson, 2003).

\section{Social Engagement}

Brown and Long argue that the traditional layout of amphitheaters and classrooms has rarely provided for social engagement among students. Jamieson states that, in order to enhance social engagement on a campus, there is a need for social spaces such as student commons, cafeterias and other hospitality areas (Brown \& Long, 2006).

\section{Sense of Campus}

Chapman calls "sense of place" a personal phenomenon that has as much to do with individuals' own experiences and cognitions as with their physical environment. With the right approach, not only the formal academic buildings but the entire campus can be designed as a learning space (Chapman, 2006; Dugdale, 2009).

\section{Campus Planning Design in the Last 20 Years}

One century ago, the only way to design a campus was with monumental architecture, which provided a sense of security. Today, the university is in communication with life, so the story to tell is completely different. It is more about permeability, more about participation. The model of the university today is more related to reality (Halsband, 2005).

In the past 20 years, more universities have recognized the importance of campus open spaces for improving the campus' image, the quality of campus life and its ability to attract students. Many of them have redesigned their open spaces.

Each of the following universities has different categories of open spaces and has used different guidelines to design them:

- University of California, Berkeley (2014): Has three types of open spaces: namely places of interaction, places of relaxation, and fields (Fig. 5).

- $\quad$ Princeton University (2016): Has four types of open spaces: greensand lawns, athletic fields, forest and tree-covered areas, and bodies of water (Fig. 6).

- University of North Carolina, Chapel Hill (2001): Has three types of open spaces namely: formal, natural, and a composite spaces of the two. Fig. 7 shows the location of these types on the map. 


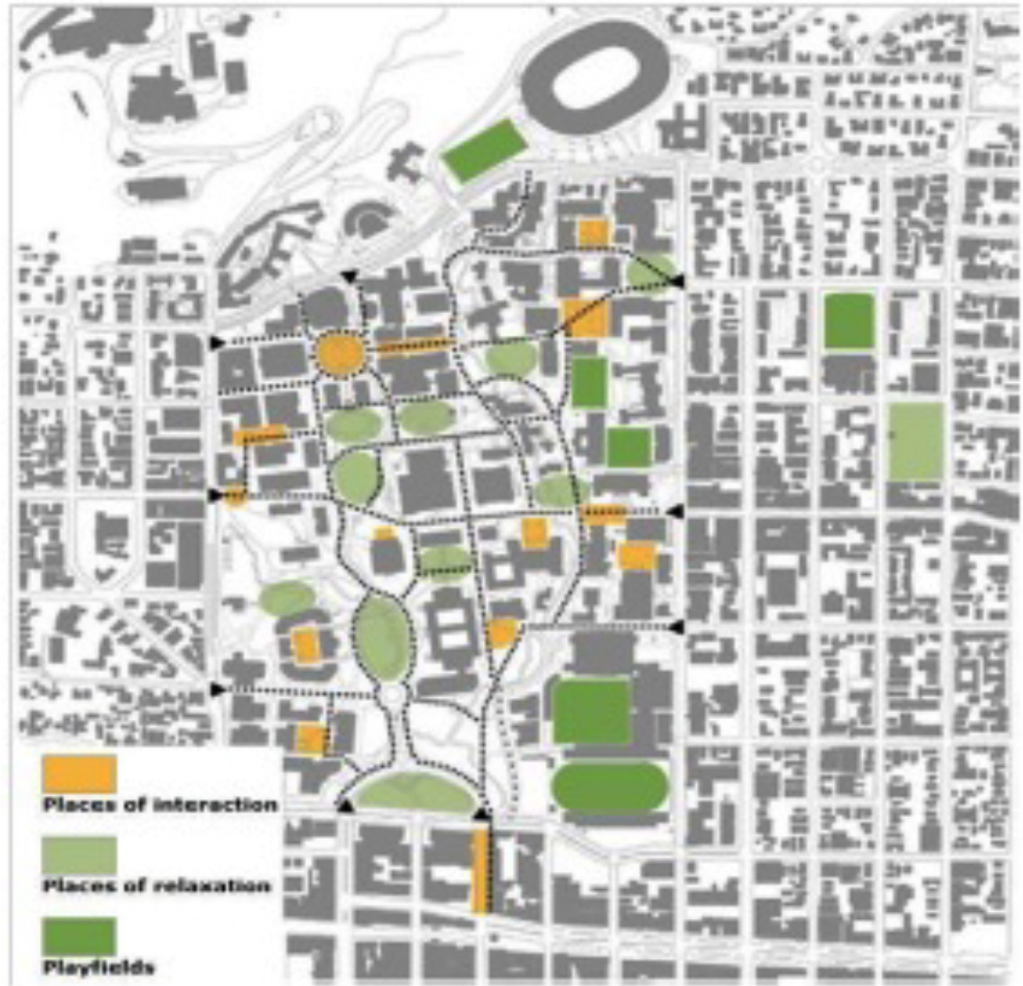

Figure 5: Types of Open Spaces, UC Berkeley (University of California Berkeley, 2019)

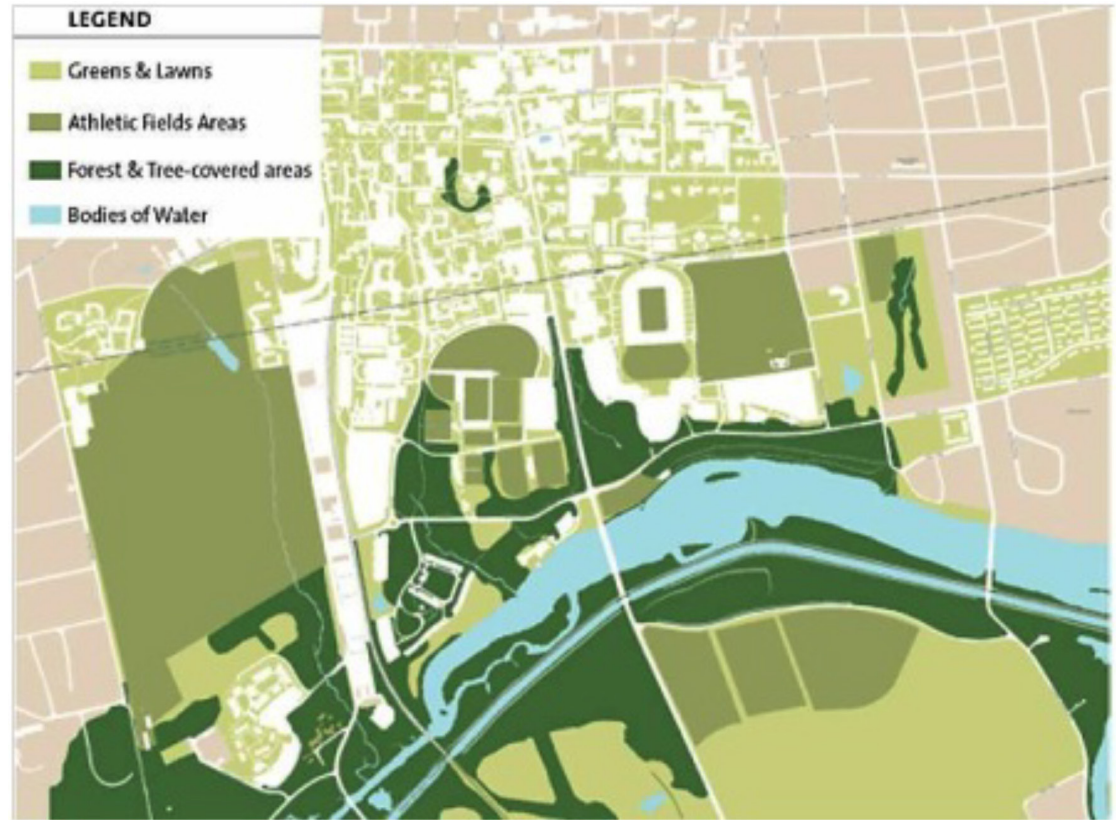

Figure 6: Types of Open Spaces, Princeton University (Princeton University.2019) 


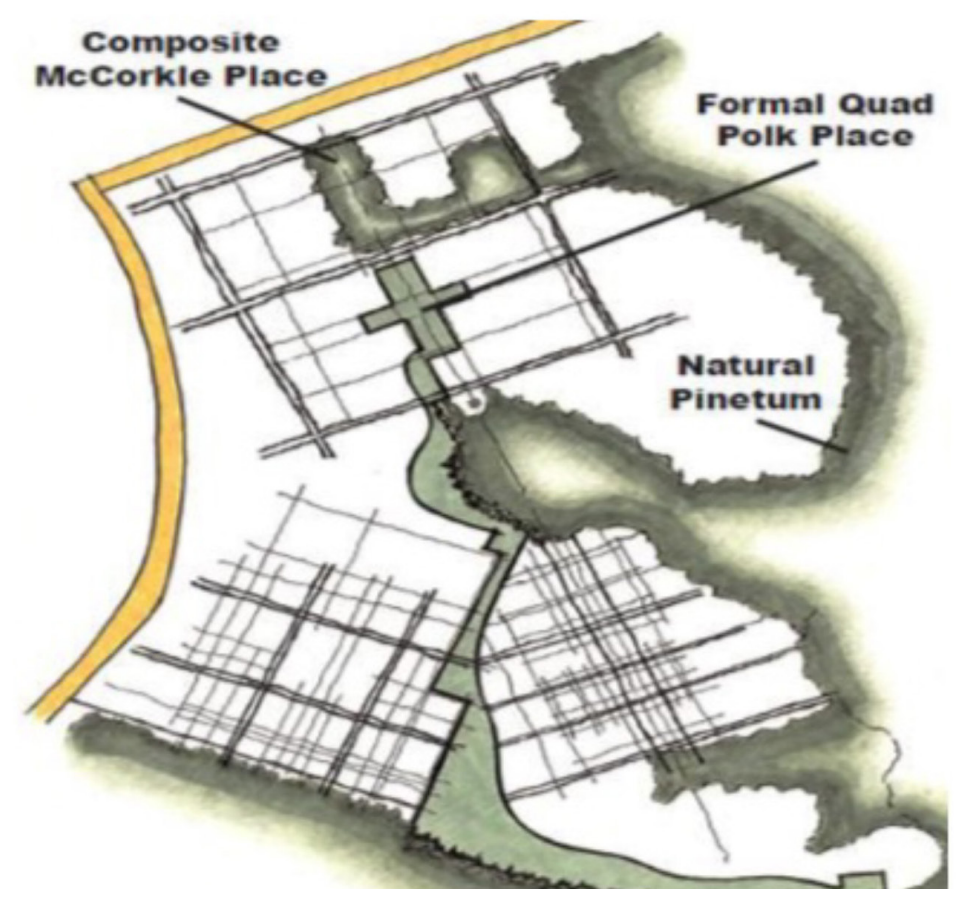

Figure 7: Types of Open Spaces, UNC, Chapel Hill (Campus Master Plan, 2019)

\section{Campus Planning Principles}

There are six basic planning and design principles concluded from the analysis part of the research that should be considered when designing a campus master plan: create a distinctive sense of place, foster a vibrant campus community, establish a unifying campus framework, maintain a pedestrian-friendly campus, accommodate transportation needs, and engage the community. The design of many universities' master plans is underpinned by those principles.

\section{Create a Distinctive Sense of Place}

As Gisolfi said when he began to consider which college to attend and visited them in the 1960s, he felt an intuitive pull to Yale - to the sense of comfort that this campus projected. He also mentioned that academic campuses typically have a distinct identity. The people familiar with the campuses at the University of Virginia, Princeton, or Stanford will conjure up images of those places at the first mention of their names.
For the most part, these visual images are not of specific buildings. What come to mind are the colors, the light, a sense of the place, the organization of green space and buildings which, because of deliberate planning, create a setting that is unique and identifiable (Gisolfi \& Associates, 2008). The campus needs to define a sense of place that sets it apart from the surrounding context. The special qualities of the campus must be further developed to achieve a distinctive campus environment.

\section{Foster a Vibrant Campus Community}

Unified academic communities should be planned with a fundamental framework of social and environmental amenities (University of Toronto, 2001). For example, the Johnson Center at George Mason University has become an animated focus for student life at the center of campus. It is a favourite spot on campus. There are a convenience store and a food court on the first floor with places to eat like Red Hot and Blue barbecue. 
There are also places to meet with study groups, as well as the Mason bookstore. The ground floor level has the JC Cinema, which shows free movies on weekends. This mix of uses that has made the Johnson Center successful should be implemented throughout the campus to promote campus life, both indoors and outdoors (George Mason University, 2020).

\section{Establish a Unifying Campus Framework}

The quality of the campus environment will be affected by new development. Therefore, the creation of a development framework is important to achieve a coherent and unified campus (University of Toronto, 2001).

\section{Maintain a Pedestrian-Friendly Campus}

Walkability is a feature that defines the campus. According to Dober (2000), one should be able to reach any destination from the campus core to academic buildings and other functions within a 10-minute walk.

\section{Accommodate Transportation Needs}

New development calls for more parking, which will affect the campus road network. To preserve the quality of the campus environment, it is important to consider transportation requirements (the pedestrian circulation and the road network) as a part of the overall campus design (George Mason University, 2020).

\section{Engage the Community}

The master plan should enhance chances for community engagement. One example of this occurred on the Prince William County, Virginia campus when it involved the local community in its development plans (Sasaki Associates and MMM Design Group, 2002).

Table 2: Evaluation table for University campus for existing types of open spaces and used principles

\begin{tabular}{|c|c|c|c|c|c|c|c|}
\hline \multirow{2}{*}{\multicolumn{2}{|c|}{$\begin{array}{c}\text { Typology of Different } \\
\text { Open spaces in } \\
\text { University Campus } \\
\text { Layout }\end{array}$}} & \multicolumn{6}{|c|}{ Campus Planning Principles } \\
\hline & & \multirow[t]{2}{*}{$\begin{array}{c}\text { Create a } \\
\text { Distinctive } \\
\text { Sense of } \\
\text { Place }\end{array}$} & \multirow[t]{2}{*}{$\begin{array}{c}\text { Foster a } \\
\text { Vibrant } \\
\text { Campus } \\
\text { Community }\end{array}$} & \multirow[t]{2}{*}{$\begin{array}{l}\text { Establish } \\
\text { a Unifying } \\
\text { Campus } \\
\text { Framework }\end{array}$} & \multirow[t]{2}{*}{$\begin{array}{l}\text { Maintain a } \\
\text { Pedestrian- } \\
\text { Friendly } \\
\text { Campus }\end{array}$} & \multirow[t]{2}{*}{$\begin{array}{l}\text { Accommodate } \\
\text { Transportation } \\
\text { Needs }\end{array}$} & \multirow[t]{2}{*}{$\begin{array}{l}\text { Engage the } \\
\text { Community }\end{array}$} \\
\hline \multirow{2}{*}{ Activity } & $\begin{array}{l}\text { Active } \\
\text { recreation }\end{array}$ & & & & & & \\
\hline & $\begin{array}{l}\text { Passive } \\
\text { recreation }\end{array}$ & & & & & & \\
\hline \multirow{2}{*}{$\begin{array}{c}\text { Open } \\
\text { Space Size }\end{array}$} & $\begin{array}{l}\text { Small } \\
\text { gathering } \\
\text { area }\end{array}$ & & & & & & \\
\hline & $\begin{array}{l}\text { Large } \\
\text { gathering } \\
\text { area }\end{array}$ & & & & & & \\
\hline \multirow{2}{*}{$\begin{array}{l}\text { Building } \\
\text { Form }\end{array}$} & $\begin{array}{l}\text { Spaces } \\
\text { shaped by } \\
\text { buildings }\end{array}$ & & & & & & \\
\hline & $\begin{array}{l}\text { Building's } \\
\text { forecourts }\end{array}$ & & & & & & \\
\hline \multirow{2}{*}{$\begin{array}{l}\text { Spiritual } \\
\text { Aspects }\end{array}$} & $\begin{array}{l}\text { Symbolic } \\
\text { spaces }\end{array}$ & & & & & & \\
\hline & $\begin{array}{c}\text { Discovered } \\
\text { spaces }\end{array}$ & & & & & & \\
\hline
\end{tabular}




\section{Planning Guidelines of Campus Outdoor Spaces}

From all the previous literature reviews for university campus design and different typology of open spaces, the paper concludes an evaluation table with design guidelines to develop any existing campus. This is an initial step to evaluate the campus and examine its hierarchy and variation of open spaces typology with the used principles. As a result, the new proposed urban vision will cover all the missing principles and create an open space network to reach a vibrant engaging community.

\section{Taibah University Campus}

Taibah University was selected as a case study for its fast expansion and lack of existing open space network, which required an action plan to solve the problem and create a green campus. It is a university in Madinah, Saudi Arabia, that was formed in 2003. The university has witnessed a vast increase in the number of its students.

In 2003, there were 7,761 registered students, according to the Statistics and Quality Center, and the number of students in TU in 2018-2019 reached 41,776 (Taibah University, 2020). The university initiated a call to redesign the campus as a step to humanize its open spaces and develop green areas by redesigning the main administration circular building and connecting it with proposed pedestrian paths connecting all the university buildings.

Unfortunately, the university did not have a design master plan from the start to all its buildings and spaces. The paper will evaluate the existing situation through a certain step as follows:

- $\quad$ Site Analysis.

- Evaluate Open Spaces Typology and Planning Principles.
- Discussion and Analysis of Questionnaire Survey.

- $\quad$ Proposed Urban Vision for TU campus.

Figure 8 shows the location of the TU campus in KSA.

\section{Site Analysis}

Taibah University's campus is gated. It has five main gates for both the male and female sides. The eastern gate is the main one, located at Prince Naïf Bin Abdulaziz Rd. Next to it is the second gate on the eastern side, which brings you to the female university section. There are two more gates on the western side of the university, located at As Salam Rd, and one more to the female section on the northern side of the university. Figure 9 shows the five entrances of TU.

The campus is a car-oriented community for all the students. It has main parking lots distributed throughout. Figure 10 describes the location and capacity of each parking area on the campus and the adjacent buildings' uses as follows:

- Two main parking areas serve the circular administration building and its surroundings, with capacity for 600 cars each.

- A parking building at the university with a capacity of 400 cars.

- The blue dotted line is a pedestrian access from a campus building to the circular building.

- The north parking lot area has a capacity of 500 cars.

Figure 11 shows the pedestrian access to the circular building from the adjacent two parking lots as a main pedestrian gate to the whole campus. 

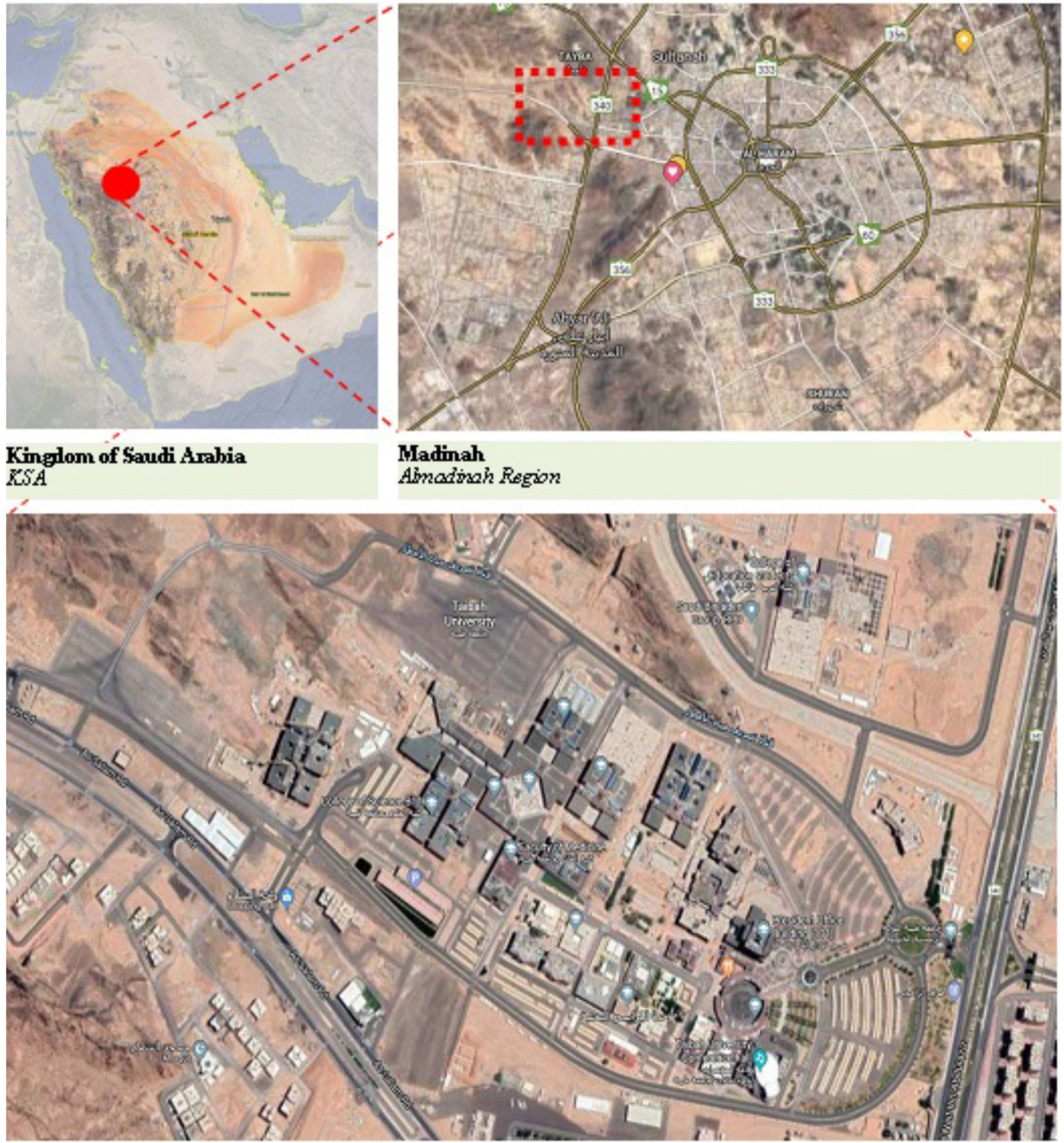

Taibah Univessity Campus Madizah

Figure 8: Location of Taibah University Campus

Evaluate Open Spaces Typology and Planning Principles

TU campus open spaces typology did not include many types of spaces due to the ongoing development process and lack of unifying master plan from the start. The campus has a distinctive sense of place by using the same architecture vocabulary in all the buildings. Unfortunately, the master plan lacks all the other design principles. Hence, the university has initiated an urgent call to redesign the campus and involve all the other planning principles to meet with and enhance all the students' needs and engage with the local community. Table 3 shows the existing open space types in the campus along with the used planning principles. 


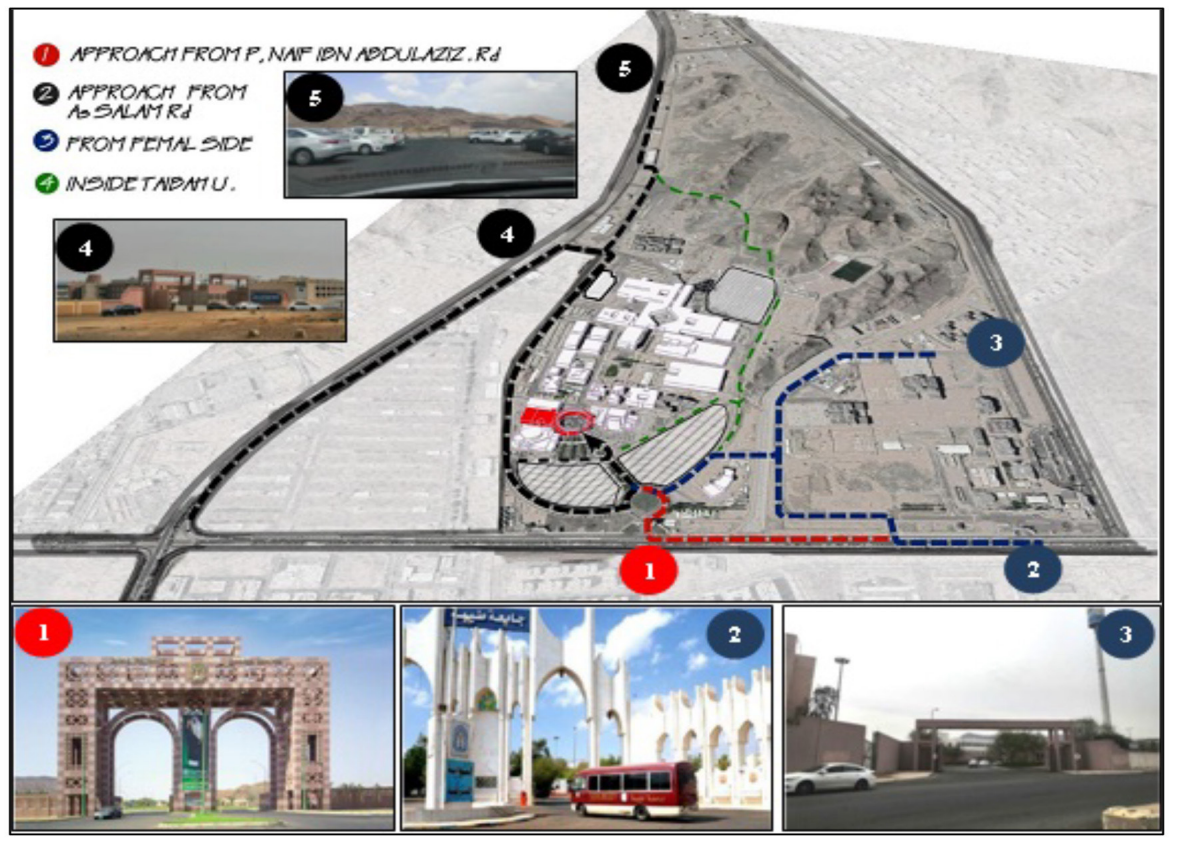

Figure 9: Five main gates of TU Campus
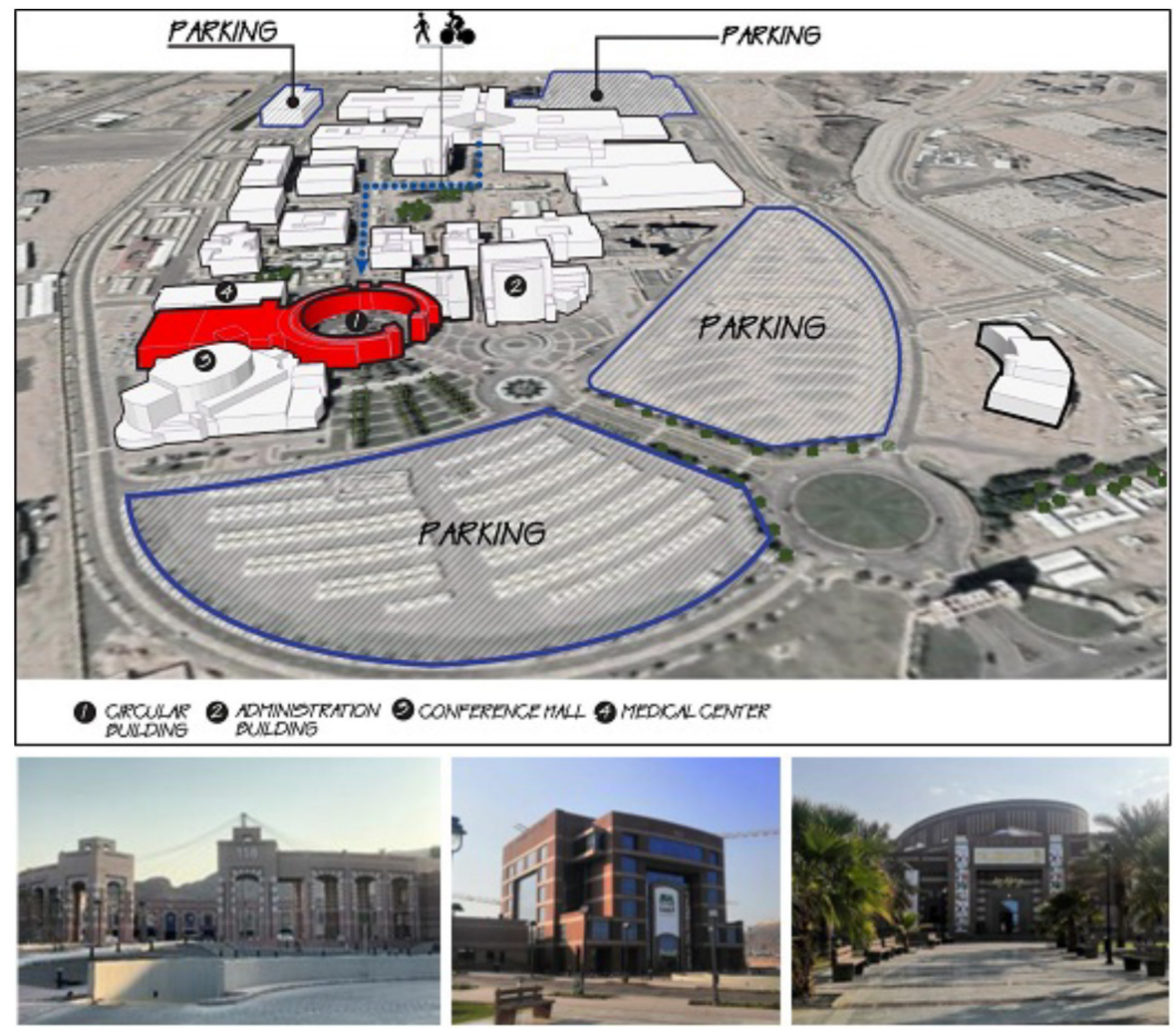

Figure 10: Parking areas and surrounding buildings on TU Campus 


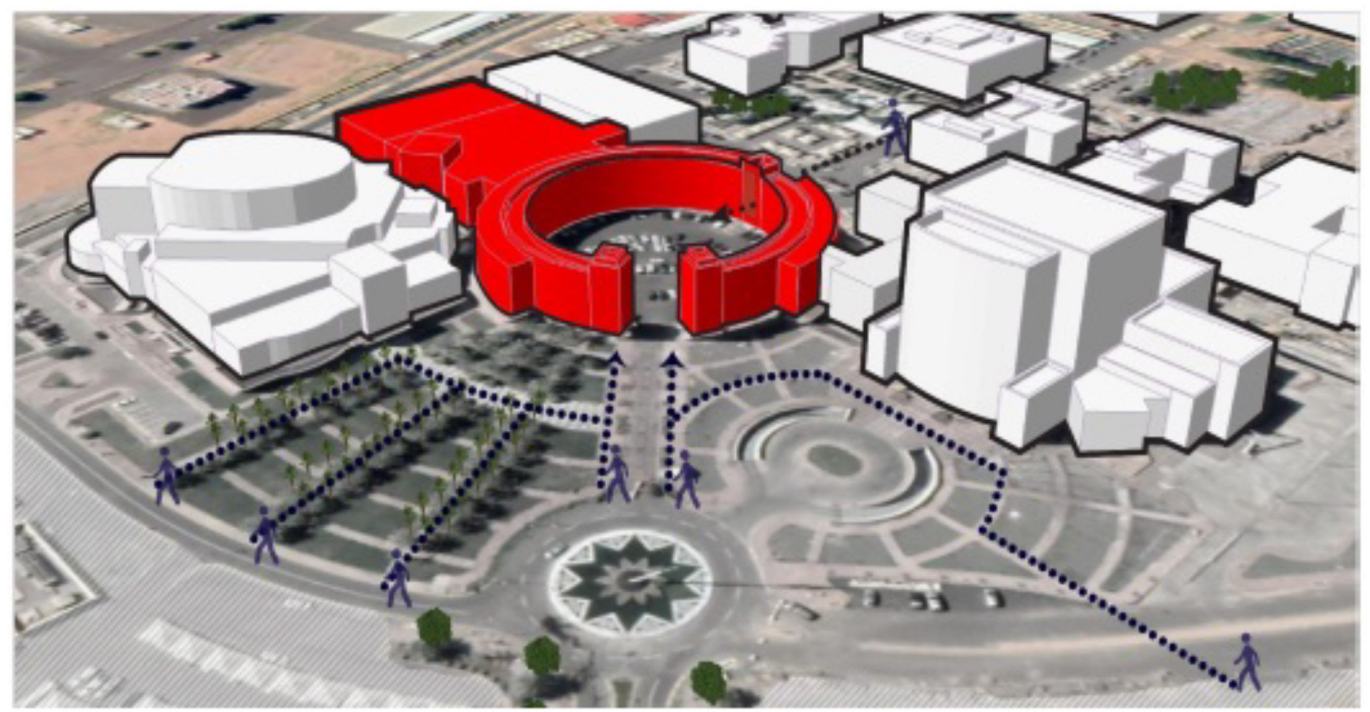

Figure 11: Pedestrian access to the circular building in TU Campus

Table 3: Evaluation table for Taibah University Campus for existing types of open spaces and used principles

\begin{tabular}{|c|c|c|c|c|c|c|c|}
\hline \multicolumn{2}{|c|}{$\begin{array}{l}\text { Typology of Different } \\
\text { Open spaces in University } \\
\text { Campus Layout }\end{array}$} & 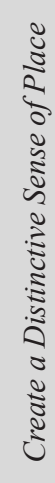 & 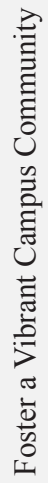 & 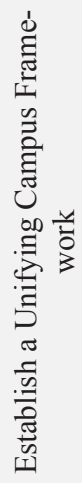 & 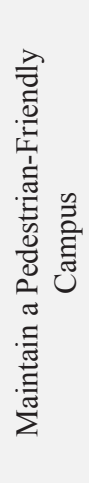 & 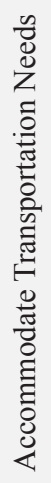 & 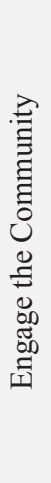 \\
\hline \multirow{2}{*}{ 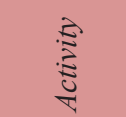 } & Active recreation & & & & & & \\
\hline & Passive recreation & & & & & & \\
\hline \multirow{2}{*}{ 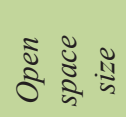 } & Small gathering area & & & & & & \\
\hline & Large gathering area & & & & & & \\
\hline \multirow{2}{*}{ 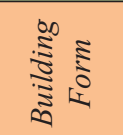 } & Spaces shaped by buildings & & & & & & \\
\hline & Building's forecourts & & & & & & \\
\hline \multirow{2}{*}{ 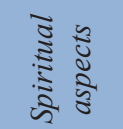 } & Symbolic spaces & & & & & & \\
\hline & Discovered spaces & & & & & & \\
\hline
\end{tabular}


As a step to cover one of the missing important principles above, the paper will conduct a questionnaire to engage the students and local community in the planning process.

\section{Discussion and Analysis of Questionnaire Survey}

Getting the community's feedback is especially important to engage the students and different target users in the development process as a step towards humanizing the TU campus. This part of the research was done by conducting a survey questionnaire of the students and employees on the campus. The questionnaire was a collaborative work with a student group in the Architectural Engineering Department at Taibah
University. The sample size was calculated with consideration of the number of students at TU's Madinah campus.

The needed sample size was 382 people, considering the confidence level of a $95 \%$ margin of error at $5 \%$ and a population size 50,655 , as shown in Figure 12. The population size was obtained from Statistics and information center in Taibah University. The survey was carried out in person with the students and employees of the university. Also, it covered as much of the university as possible, with each survey group covering different areas and working hours in the early morning, at noon, and in the afternoon to cover all the time periods for all the students, as shown in Figure 13.

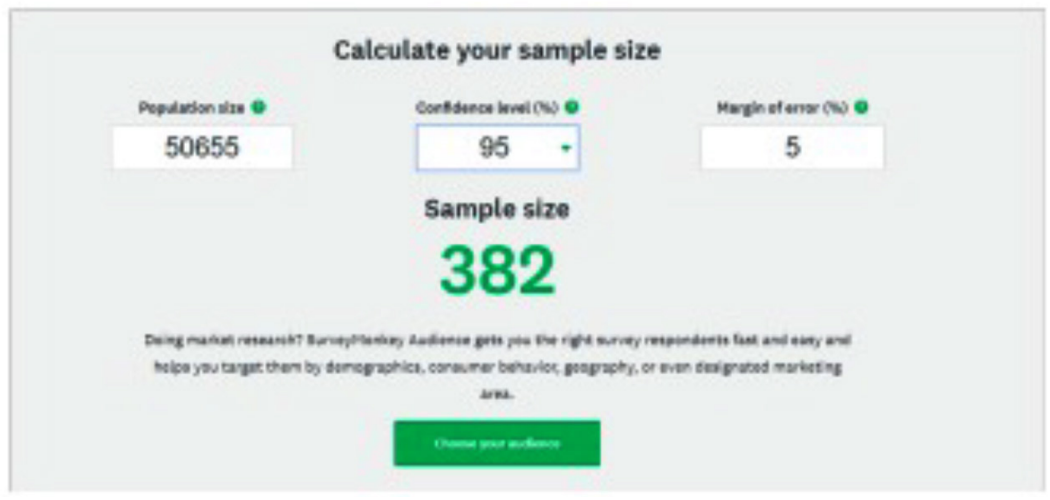

Figure 12: Sample size calculator of student Sample (Survey Monkey, 2019)

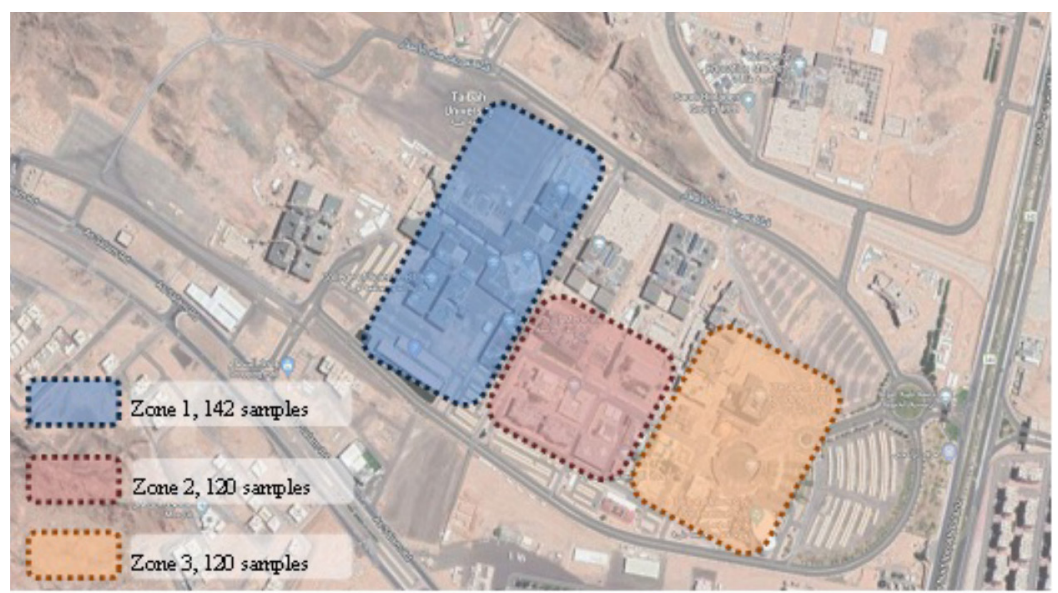

Figure 13: Distribution of student survey sample on TU Campus 
Tables 4 and 5 show some samples of the questionnaire results and their implications for the next stage to propose an urban development plan for the campus.

Table 4: Results of Questionnaire Survey Part 1

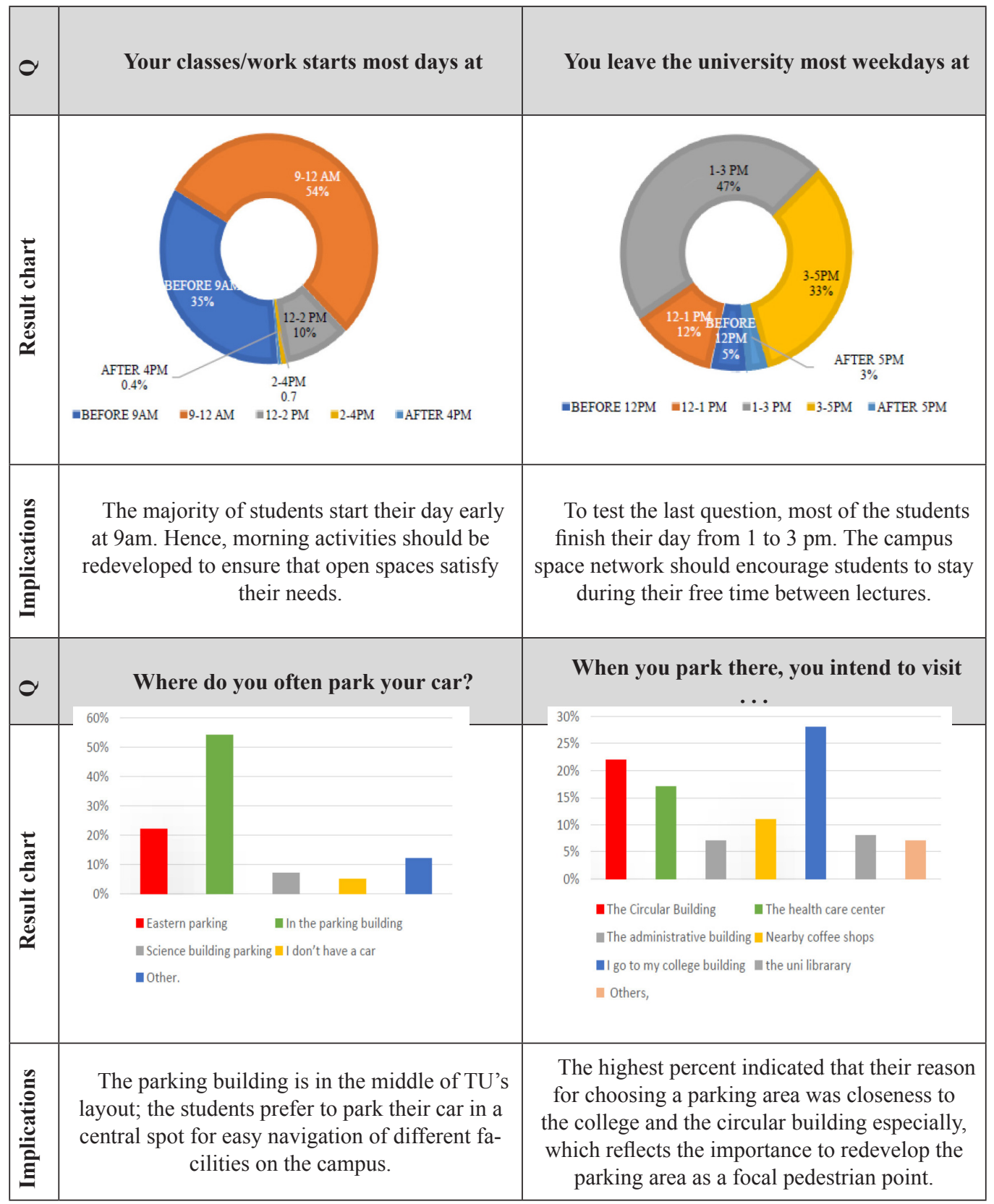


Table 5: Results of Questionnaire Survey Part 2

\begin{tabular}{|c|c|}
\hline 0 & What activities do you do in your spare time? \\
\hline 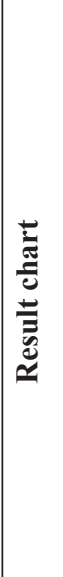 & $\begin{array}{l}40 \% \\
35 \% \\
30 \% \\
25 \%\end{array}$ \\
\hline 号 & $\begin{array}{l}\text { The most desirable activity for the students in their free time is to hang out with friends, then study } \\
\text { and do homework. However, the campus lacks entertainment facilities and areas equipped for } \\
\text { students to gather and finish their different assignments, either alone or in groups. This raises the } \\
\text { need to design a workspace in the circular building with multiple uses to satisfy the needs both to } \\
\text { hang out and to study. }\end{array}$ \\
\hline O & Are there certain activities or services you wish to have at the university? \\
\hline 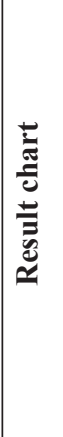 & $\begin{array}{l}25 \% \\
20 \% \\
15 \% \\
10 \% \\
5 \% \\
\ldots\end{array}$ \\
\hline 曾 & $\begin{array}{l}\text { The answers really reflect what the university lacks, starting with green areas with shaded places } \\
\text { and cafes. Meanwhile, having a close working space would encourage students to stay on the } \\
\text { campus longer to finish their work and still enjoy the greenery and other facilities on the campus. }\end{array}$ \\
\hline
\end{tabular}


Figure 14 shows the students' answers for the subjects that most attract their attention in general. Their answers reflect their needs and the different possible uses of the new design of the circular building.

\section{Proposed Urban Vision for TU campus}

In this part of the research, a conceptual plan for an urban vision for Taibah University's campus will be proposed to include all the missing planning principles in the existing campus. Figure 15 and 16 illustrates the most important urban development actions to be taken to deal with all the problems derived from the literature study, site analysis, and student survey. These actions can be listed as follows:

- Design an arched path connecting the open spaces network on the campus to facilitate the students' circulation between the university's colleges. This path will connect the master plan from east to west for only pedestrians and cyclists, starting from the circular building near the eastern gate and ending at the western edge.

- Create successful campus open spaces considering the local hot climate by designing most of the pedestrian movement in shaded areas with more interactive landscape furniture elements.

- Design a variety of open space typologies on the campus according to their area, type of activity, and location on the campus to enhance formal and informal learning spaces. This will give a special character to every zone in the layout and create a different visual experience for the students.

- Propose multiple uses for the circular building as a starting point for the arched path from the western gate.

- Design a complete circulation network to connect all the car parking lots with the arched path through a pedestrian-friendly shaded street.

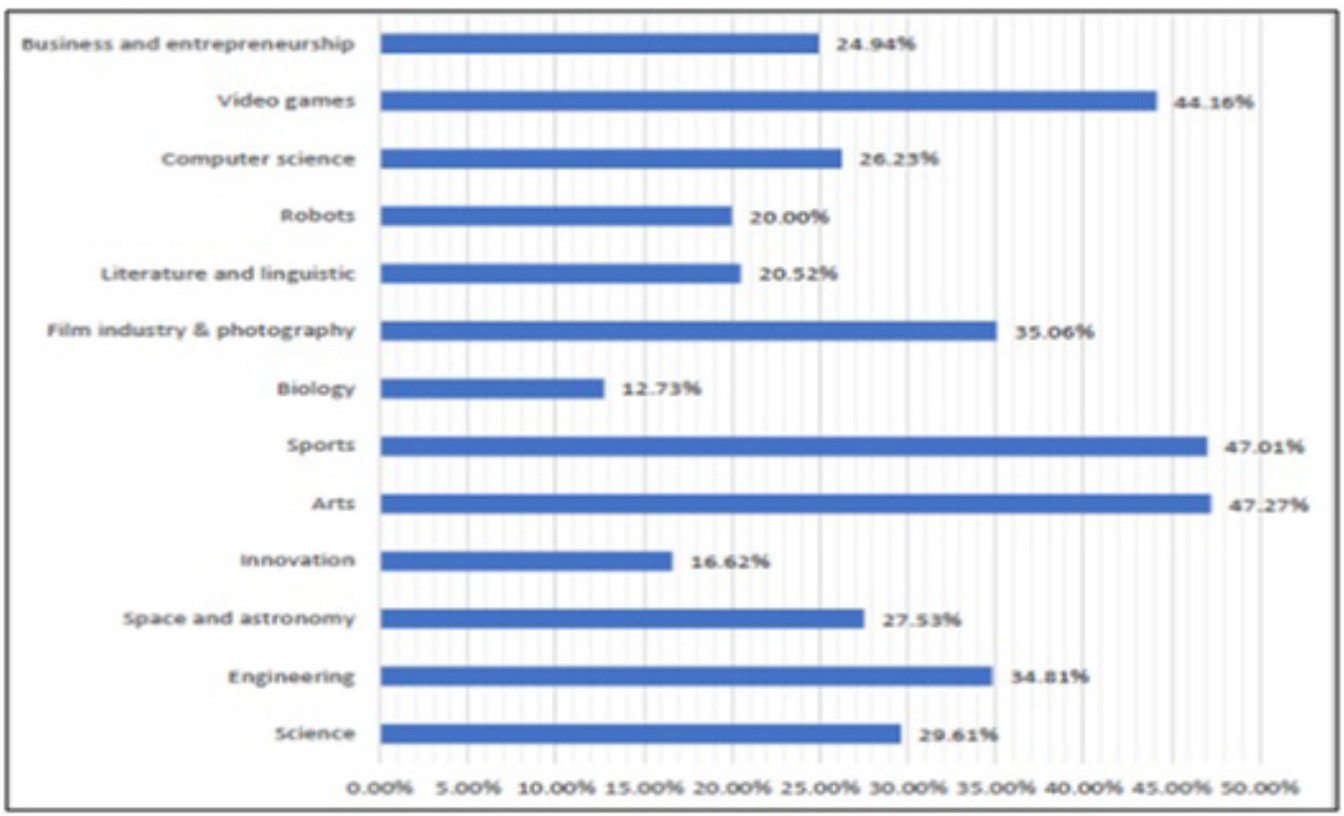

Figure 14: Which of the Following Subjects Draws Your Attention the Most (Select 5 at Most)? 


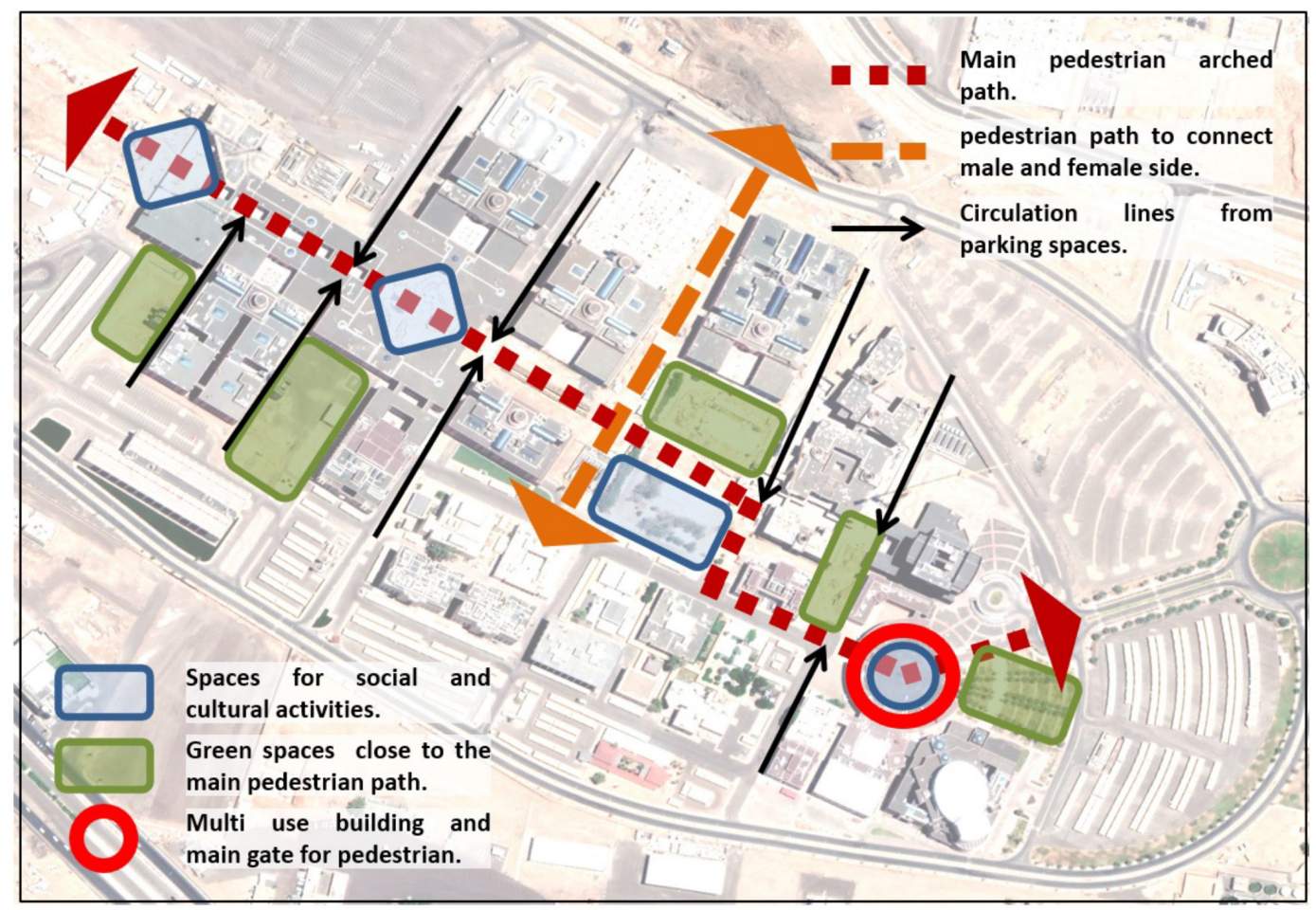

Figure 15: Future Urban Development Plan of TU campus

\section{Conclusions}

University campuses are a very important part of any city's urban fabric. Even if they are gated, as in the case on the TU campus, they can still engage the local community. Campuses' layout of open spaces should not be designed for educational purposed only, but also for social and cultural activities. Hence, the most important factor to take into consideration in the design or development process is to promote pedestrian movement instead of creating a totally car-oriented environment. By analyzing TU's campus, the researcher arrived at some important conclusions about achieving a more walkable community on the campus:

- There is no typology or hierarchy of open spaces network on the TU campus. The urban development vision proposed earlier is a step toward solving this problem that must be followed up.

- A lack of site furniture (shade and seats) limits the usefulness of open spaces. The study suggests adding more vegetation and shaded seating areas to encourage the use of the open spaces.

- TU's campus is a car-oriented community. It needs to promote pedestrian and bicycle movement by designing suitable lanes for both to connect all the campus spaces and colleges.

- $\quad$ Any proposed design for the TU campus should include buildings in an interactive open space network. This will certainly enhance the opportunity for interaction between the students and academics for the benefit of both.

- Open spaces - especially large ones — should avoid fixed design elements like benches or theaters. Instead, mobile furnishing should be encouraged, which will allow the space to be reshaped for different uses. 


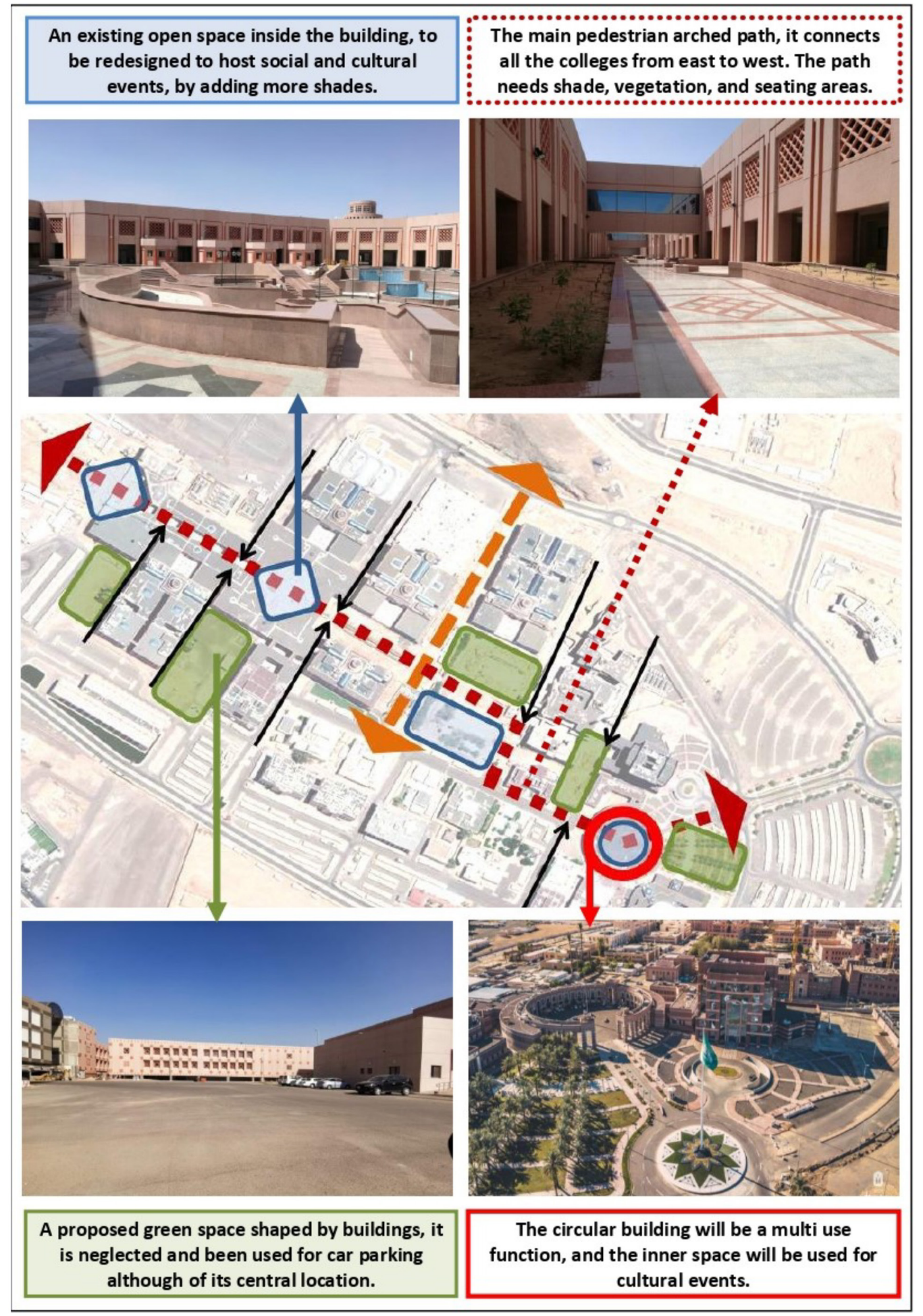

Figure 16: Proposed open space typology of TU campus 
For the findings of this research to be generalised and reliable in achieving the objective of this research, some additional recommendations are addressed as follows:

- Involve students and employees in the design process to create effective open spaces that meet their actual needs.

- Provide continuous shaded landscapes for pedestrian paths to protect from hot weather conditions, present an appealing and unified visual image of the campus, and encourage students to walk.

- The following are recommendations for future studies to be done on the TU campus for more continuous development of the urban environment:

- Study how to make the campus safe at night by analyzing the night lighting distribution on campus.

- Study "friendly transportation services" on the university campus, such as bicycle lanes and racks, when considering upgrading or expanding the colleges.

- There is a direct relation between the physical environment on the TU campus and its user characteristics. Especially given the radical social changes taking place in Saudi Arabia, this must be examined over time to study how social changes will affect the future type of shared activities after male and female sectors are no longer fully separated.

\section{Acknowledgements}

The Author would like to acknowledge all the enrolled students in the Architectural Engineering Department at Taibah University in the capstone project who directly contributed to distributing the student and employee survey among the selected sample in the campus. Their names are as follows: Khaled Elsaadi, Ziyad AlSehli, Mosab Aljehani, Omar Jarrah, Abdullah Nahar, Abdulsalam Jumah, Almuthna Alqeel, and Ibrahim Hakeem.
Special thanks to Muhammed Al-Shareef for his work and effort in the site analysis and statistical part.

\section{References}

Abu-Ghazzeh, T. (1999). Communicating behavioral research to campus design. Environment and Behavior, 31(6), 764-804.

Alhusban, A., Alhusban, S., \& Al-Betawi, Y. (2019). The degree of the Hashemite University students' desires, needs, and satisfaction with their campus urban design. Journal of Place Management and Development, 12(3), 408-448.

Bacharel Carreira, M. (2015). In-between formality and informality learning spaces in university context. Universidade de Lisboa.

Brown, M., \& Long, P. (2006). Trends in learning space design. In Diana G. Oblinger (Ed.), Learning spaces, 9.1-9.11. Louisville, CO: Educause.

Campos Calvo-Sotelo, P. (2011). Innovative spaces for university excellence: A study of paradigms of optimization in teaching and adaptation to the European higher education area. Madrid: Ministerio de Educación.

Campus Master Plan. (2019). Retrieved 15 December 2019, from https://facilities.unc. edu/master-plan/

Chapman, M. P. (2006). American Places. In Search of the Twenty-First Century Campus. Westport, CT: Greenwood Publishing Group.

Conceição, P., \& Heitor M. (2001). Universities in the learning economy: Balancing institutional integrity with organizational diversity. In The globalizing learning economy: Major socio-economic trends and European Innovation Policies, 83-96. Oxford University Press.

Conceição, P., \& Heitor, M. (1999). On the role of the university in the knowledge economy. 
Science and Public Policy, 26(1), 37-51.

Dober, R. P. (2000). Campus landscape: Functions, forms, features. Hoboken: John Wiley \& Sons.

Dugdale, S. (2009). Space strategies for the new learning landscape. Educause Review, 44(2), 50-63.

George Mason University. (2020). Parking Services. Retrieved 15 January 2020, http:// parking.gmu.edu/.

Gulwadi, G., Mishchenko, E., Hallowell, G., Alves, S., \& Kennedy, M. (2019). The restorative potential of a university campus: Objective greenness and student perceptions in Turkey and the United States. Landscape and Urban Planning, 187(2019), 36-46.

Hajrasouliha, A. (2016). Campus score: Measuring university campus qualities. Landscape and Urban Planning, 158(2016), 166-176.

Halsband, F. (2005). Campuses in Place. Places, 17(1), 4-11.

Isiaka, A., \& Siong, H. (2008). Developing sustainable index for university campus. In EASTS International Symposium on Sustainable Transportation Incorporating, Malaysian Universities Transport Research Forum Conference.

Jamieson, P. (2003). Designing more effective on-campus teaching and learning spaces: A role for academic developers. International Journal for Academic Development, 8(12). 119-133.

Kenney, D., Dummont, R., \& Kenney, G. (2005). Mission and place: Strengthening learning and community through campus design. Westport, CT: Praeger Publishers.

Khadem, N., Kabir, M., Banerjee, S., \& Jeihani, M. (2019). Bike station suitability on university campus using Origin-Destination Matrix-A Morgan State University case Study. Urban Science, 3(3), 74.

Kolb, A., \& Kolb, D. (2005). Learning styles and learning spaces: Enhancing experiential learning in higher education. Academy of Management Learning \& Education, 4(2), 193-212.

Lenz-Rashid, S. (2018). An urban university campus support program for students from foster care: Services and outcomes. Children and Youth Services Review, 94(3), 180-185.

Marcus, C. (1998). Campus outdoor spaces. In C. C. Marcus \& C. Francis (Eds.), People places: Design guidelines for urban open space. Hoboken: John Wiley \& Sons.

Marcus, C., \& Francis C. (1997). People places: Design guidelines for urban open space. Hoboken: John Wiley \& Sons.

Özkan, D., Alpak, E., \& Var, M. (2017). Design and construction process in campus open spaces: A case study of Karadeniz Technical University. URBAN DESIGN International, 22(3), 236-252.

Peter Gisolfi \& Associates. (2008). Finding the place of architecture in the landscape. Mulgrave, Australia: Images Publishing.

Princeton University. (2019). Princeton Campus Plan: Evolution of a Campus. Retrieved 25 November 2019, from https:/campusplan. princeton.edu/current-campus-plan

Saadatian, O., Sopian, K., \& Salleh, E. (2013). Adaptation of sustainability community indicators for Malaysian campuses as small cities. Sustainable Cities and Society, 6(2013), 40-50.

Salama, A. (2008). When good design intentions do not meet users' expectations: Exploring Qatar University campus outdoor spaces. International Journal of Architectural Research, 2(2), 57-60.

Sasaki Associates \& MMM Design Group. (2002). George Mason University Master Plan. https://facilities.gmu.edu/wp-content/ uploads/universitymasterplan.pdf.

Shepley Bulfinch Richardson \& Abbott. (2007). Appendix G: Open space typologies. In University of Denver - Land Use Plan Update I, 17-28. 
SurveyMonkey. (2019). Online Survey Tool. Retrieved 14 October 2019, from https:// www.surveymonkey.com/

Taibah University, 2020. Deanship of Student Affairs. Retrieved 20 March 2020, from https://www.taibahu.edu.sa/Pages/EN/ Sector/SectorPage.aspx? ID $=38$

Turner, P. (1984). Campus: An American planning tradition. Cambridge, MA: MIT Press.

University of California, Berkeley, (2014). New Century Plan - A strategic framework for capital investment at UC Berkeley. Retrieved 12 November 2019, from http://www.cp.berkeley.edu/ncp/goals/ interactivecampus.html.

University of California, Berkeley. (2019). Retrieved 12 November 2019, from https:// www.berkeley.edu/

University of North Carolina, Chapel Hill. (2001). Campus wide Design Guidelines
- Open Space Types. http://www.facilities. unc.edu/planspolicies/campusmasterplan.

University of Toronto, (2001). Campus Planning Principles. http://www.updc.utoronto.ca/ re/Planning_Resources/Campus_Planning Principles.htm.

Way, T. (2016). The urban university 's hybrid campus. Journal of Landscape Architecture, 11(1), 42-55.

Yıldız, D., \& Sener H. (2003). Factors affecting the use value of campus outdoor spaces. In Nuran Zeren Gülersoy, Nur Esin, and Ahsen Özsoy (Eds.), Quality of urban life: Policy versus practice (pp. 609-621). Istanbul Technical University.

Yıldız, D., \& Sener H. (2006). Binalarla Tanımlı Dıs Mekanların Kullanım Değeri Analiz Modeli. ITÜ Dergisi/a, Mimarlık, Planlama, Tasarım, 5(1), 115-127. 